\title{
Front Matter: Volume 8647
}

, "Front Matter: Volume 8647," Proc. SPIE 8647, Next-Generation Optical Communication: Components, Sub-Systems, and Systems II, 864701 (11 July 2013); doi: 10.1117/12.2020812

SPIE. Event: SPIE OPTO, 2013, San Francisco, California, United States 


\section{PROCEEDINGS OF SPIE}

\section{Next-Generation Optical Communication: Components, Sub-Systems, and Systems II}

Guifang Li

Editor

5-7 February 2013

San Francisco, California, United States

Sponsored and Published by

SPIE 
The papers included in this volume were part of the technical conference cited on the cover and title page. Papers were selected and subject to review by the editors and conference program committee. Some conference presentations may not be available for publication. The papers published in these proceedings reflect the work and thoughts of the authors and are published herein as submitted. The publisher is not responsible for the validity of the information or for any outcomes resulting from reliance thereon.

Please use the following format to cite material from this book:

Author(s), "Title of Paper," in Next-Generation Optical Communication: Components, Sub-Systems, and Systems II, edited by Guifang Li, Proceedings of SPIE Vol. 8647 (SPIE, Bellingham, WA, 2013) Article CID Number.

ISSN: 0277-786X

ISBN: 9780819494160

Published by

SPIE

P.O. Box 10, Bellingham, Washington 98227-0010 USA

Telephone +1 3606763290 (Pacific Time) · Fax +1 3606471445

SPIE.org

Copyright (C) 2013, Society of Photo-Optical Instrumentation Engineers.

Copying of material in this book for internal or personal use, or for the internal or personal use of specific clients, beyond the fair use provisions granted by the U.S. Copyright Law is authorized by SPIE subject to payment of copying fees. The Transactional Reporting Service base fee for this volume is $\$ 18.00$ per article (or portion thereof), which should be paid directly to the Copyright Clearance Center (CCC), 222 Rosewood Drive, Danvers, MA 01923. Payment may also be made electronically through CCC Online at copyright.com. Other copying for republication, resale, advertising or promotion, or any form of systematic or multiple reproduction of any material in this book is prohibited except with permission in writing from the publisher. The CCC fee code is 0277-786X/13/\$18.00.

Printed in the United States of America.

Publication of record for individual papers is online in the SPIE Digital Library.

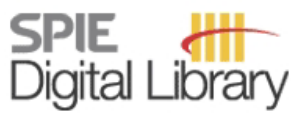

SPIEDigitalLibrary.org

Paper Numbering: Proceedings of SPIE follow an e-First publication model, with papers published first online and then in print and on CD-ROM. Papers are published as they are submitted and meet publication criteria. A unique, consistent, permanent citation identifier (CID) number is assigned to each article at the time of the first publication. Utilization of CIDs allows articles to be fully citable as soon as they are published online, and connects the same identifier to all online, print, and electronic versions of the publication. SPIE uses a six-digit CID article numbering system in which:

- The first four digits correspond to the SPIE volume number.

- The last two digits indicate publication order within the volume using a Base 36 numbering system employing both numerals and letters. These two-number sets start with 00, 01, 02, 03, $04,05,06,07,08,09,0 \mathrm{~A}, 0 \mathrm{~B} \ldots \mathrm{OZ}$, followed by 10-1Z, 20-2Z, etc.

The CID number appears on each page of the manuscript. The complete citation is used on the first page, and an abbreviated version on subsequent pages. Numbers in the index correspond to the last two digits of the six-digit CID number. 


\section{Contents}

vii Conference Committee

TERABIT CAPACITY, FLEXIBLE-GRID OPTICAL TRANSMISSION SYSTEMS AND ADVANCED ACCESS NETWORK: JOINT SESSION WITH CONFERENCES 8645, 8646, AND 8647

864703 Field trial for the mixed bit rate at 100G and beyond (Invited Paper) [8647-2]

J. Yu, Z. Jia, Z. Dong, H.-C. Chien, ZTE USA (United States)

ORBITAL ANGULAR MOMENTUM(OAM)- MULTIPLEXING TECHNOLOGIES

864705 Optical vortices: an innovative approach to increase spectral efficiency by fiber modedivision multiplexing (Invited Paper) [8647-5]

P. Boffi, P. Martelli, A. Gatto, M. Martinelli, Politecnico di Milano (Italy)

864706 Performance analysis of spectrally efficient free-space data link using spatially multiplexed orbital angular momentum beams [8647-6]

H. Huang, Y. Ren, Y. Yan, Y. Yue, N. Ahmed, A. Bozovich, Univ. of Southern California (United States); S. J. Dolinar, Jet Propulsion Lab. (United States); A. E. Willner, Univ. of Southern California (United States)

864709 Few-mode fiber transmission with in-line few-mode erbium-doped fiber amplifier (Invited Paper) [8647-8]

E. Ip, NEC Labs. America (United States); M.-J. Li, K. Bennett, S. Bickham, Corning Inc. (United States); Y.-K. Huang, A. Tanaka, E. Mateo, J. Hu, T. Wang, NEC Labs. America (United States); A. Korolev, K. Koreshkov, W. Wood, Corning Inc. (United States); J. Liñares, C. Montero, V. Moreno, X. Prieto, Univ. of Santiago de Compostela (Spain); Y. Yano, Y. Aono, T. Tajima, K. Fukuchi, NEC Corp. (Japan)

MODE- AND SPACE-MULTIPLEXING TECHNOLOGIES

8647 OB Few-mode fiber for optical MIMO transmission with low-computational complexity (Invited Paper) [8647-9]

T. Sakamoto, T. Mori, T. Yamamoto, F. Yamamoto, NTT Corp. (Japan)

8647 OC Separation of LP modes using volume holographic demultiplexer with a dual-wavelength method for mode division multiplexing [8647-11]

K. Kawabata, A. Okamoto, Hokkaido Univ. (Japan); S. Honma, Univ. of Yamanashi (Japan); Y. Wakayama, Hokkaido Univ. (Japan); K. Sato, Hokkai-Gakuen Univ. (Japan);

A. Tomita, Hokkaido Univ. (Japan) 
NEXT GENERATION OPTICAL FIBERS: JOINT SESSION WITH CONFERENCES 8646 AND 8647

8647 OE Modeling linear and nonlinear transmission in multi-mode fibers (Invited Paper) [8647-13]

C. Antonelli, A. Mecozzi, Univ. of L'Aquila (Italy); M. Shtaif, Tel Aviv Univ. (Israel)

8647 OF Multicore fiber with one-ring structure (Invited Paper) [8647-14]

S. Matsuo, Y. Sasaki, I. Ishida, K. Takenaga, Fujikura Ltd. (Japan); K. Saitoh, M. Koshiba,

Hokkaido Univ. (Japan)

MODELING AND SIGNAL PROCESSING IN COHERENT COMMUNICATION SYSTEM (DSP)

8647 OG Mathematical and system level HW description DSP algorithms modeling investigation in an experimental 100G optical coherent system [8647-18]

V. B. Ribeiro, F. A. Silva, J. C. R. F. Oliveira, L. V. Franz, E. O. Schneider, C. Moretti,

S. M. Ranzini, CPqD Foundation (Brazil)

$8647 \mathrm{OH}$ Quasi-phase-matched electro-optic modulators for high-speed signal processing

[8647-16]

J. E. Toney, V. E. Stenger, J. Busch, P. Pontius, M. Clabough, A. Pollick, S. Sriram, SRICO, Inc.

(United States)

8647 Ol Optical transmission modeling by means of Volterra series (Invited Paper) [8647-15]

A. L. Teixeira, Univ. of Aveiro and Instituto de Telecomunicações (Portugal) and Nokia Siemens Networks Portugal S.A. (Portugal); J. D. Reis, Nokia Siemens Networks Portugal S.A. (Portugal)

8647 OJ Filter-bank based digital sub-banding ASIC architecture for coherent optical receivers (Invited Paper) [8647-17]

M. Nazarathy, A. Tolmachev, Technion-Israel Institute of Technology (Israel)

8647 OK Complexity-reduced digital nonlinear compensation for coherent optical system [8647-19] Z. Tao, L. Dou, W. Yan, Y. Fan, L. Li, Fujitsu R\&D Ctr. (China); S. Oda, Y. Akiyama, Fujitsu Labs. Ltd. (Japan); H. Nakashima, T. Hoshida, J. C. Rasmussen, Fujitsu Ltd. (Japan)

HIGH-ORDER MODULATION FORMATS AND CODING FORMATS: JOINT SESSION WITH CONFERENCES 8646 AND 8647

8647 OL Performance comparison of RZ pulse formats in PDM-16QAM high rates transmissions with optical pre-filtering [8647-20]

E. P. Silva, L. H. H. Carvalho, M. L. Lopes, V. B. Ribeiro, CPqD (Brazil); A. C. Bordonalli, Univ. of Campinas (Brazil); J. C. R. F. Oliveira, CPqD (Brazil)

NOVEL LIGHT SOURCES, AMPLIFIERS AND DEVICES: JOINT SESSION WITH CONFERENCES 8646 AND 8647

864700 Supercontinuum generation in dispersion-tailored lead-silicate fiber taper [8647-23] H. Hu, W. Li, S. Ma, N. K. Dutta, Univ. of Connecticut (United States) 
8647 OP A new scheme for novel all-optical wavelength conversion with ultrabroad conversion tunability and modulation-transparency [8647-24]

Y. Gong, N. Copner, K. Li, J. Huang, J. J. Martinez, D. Rees-Whippey, S. Carver, Univ. of Glamorgan (United Kingdom)

Author Index 
Proc. of SPIE Vol. $8647864701-6$

Downloaded From: https://www.spiedigitallibrary.org/conference-proceedings-of-spie on 26 Apr 2023 Terms of Use: https://www.spiedigitallibrary.org/terms-of-use 


\section{Conference Committee}

Symposium Chair

David L. Andrews, University of East Anglia Norwich (United Kingdom)

Symposium Cochairs

Alexei L. Glebov, OptiGrate Corporation (United States)

Klaus P. Streubel, OSRAM GmbH (Germany)

Program Track Chair

Benjamin B. Dingel, Nasfine Photonics, Inc. (United States)

Conference Chair

Guifang Li, CREOL, The College of Optics and Photonics, University of Central Florida (United States)

Conference Program Committee

Yi Cai, Huawei Technologies Company, Ltd. (United States)

Gabriella Cincotti, Università degli Studi di Roma Tre (Italy)

Benjamin B. Dingel, Nasfine Photonics, Inc. (United States)

John D. Downie, Corning Inc. (United States)

Ronald Freund, Fraunhofer-Institut für Nachrichtentechnik Heinrich-

Hertz-Institut (Germany)

Masataka Nakazawa, Tohoku University (Japan)

loannis Roudas, University of Patras (Greece)

Kunimasa Saitoh, Hokkaido University (Japan)

Akihide Sano, NTT Network Innovation Laboratories (Japan)

Atul K. Srivastava, NEL America, Inc. (United States)

Fatih Yaman, NEC Laboratories America, Inc. (United States)

Xiang Zhou, AT\&T Laboratories Research (United States)

\section{Session Chairs}

1 Optical Communication Plenary Session: Joint Session with Conferences 8645,8646 , and 8647

Benjamin B. Dingel, Nasfine Photonics, Inc. (United States)

Atul K. Srivastava, NEL America, Inc. (United States) 
2 Terabit Capacity, Flexible-Grid Optical Transmission Systems and Advanced Access Network: Joint Session with Conferences 8645, 8646, and 8647

Guifang Li, CREOL, The College of Optics and Photonics, University of Central Florida (United States)

Werner Weiershausen, Deutsche Telekom AG (Germany)

3 Integrated Network Photonics Devices for Next-Generation Network: Joint Session with Conferences 8645, 8646, and 8647

Martin Bouda, Fujitsu Network Communications Inc. (United States)

Benjamin B. Dingel, Nasfine Photonics, Inc. (United States)

4 Orbital Angular Momentum(OAM)-Multiplexing Technologies

Taiji Sakamoto, Nippon Telegraph and Telephone Corporation (Japan)

5 Mode- and Space-Multiplexing Technologies

Fatih Yaman, NEC Laboratories America, Inc. (United States)

6 Next Generation Optical Fibers: Joint Session with Conferences 8646 and 8647

Ronald Freund, Fraunhofer-Institut für Nachrichtentechnik HeinrichHertz-Institut (Germany)

7 Modeling and Signal Processing in Coherent Communication System (DSP)

Mark Shtaif, Tel Aviv University (Israel)

8 High-Order Modulation Formats and Coding Formats: Joint Session with Conferences 8646 and 8647

Julio C. R. F. Oliveira, CpqD Foundation (Brazil)

Guifang Li, CREOL, The College of Optics and Photonics, University of Central Florida (United States)

9 High-Speed Components and Signal Monitoring: Joint Session with Conferences 8646 and 8647

Werner Weiershausen, Deutsche Telekom AG (Germany)

10 Novel Light Sources, Amplifiers and Devices: Joint Session with Conferences 8646 and 8647

Achyut K. Dutta, Banpil Photonics, Inc. (United States) 